\title{
Occurrence of Diseases in Floricultural Crops in and around Jorhat, Assam
}

\author{
Munmi Borah*, Moyurtrishna Rajkhowa and Sakendar Ali
}

Dept. of Plant Pathology, Assam Agricultural University, Jorhat, Assam (785 013), India

\author{
Corresponding Author \\ Munmi Borah \\ e-mail: mborah56@gmail.com
}

\author{
Article History \\ Article ID: IJEP0294 \\ Received in $12^{\text {th }}$ March, 2019 \\ Received in revised form $29^{\text {th }}$ April, 2019 \\ Accepted in final form 15 ${ }^{\text {th }}$ May, 2019
}

\begin{abstract}
The objective of this study was to identify pathogenic diseases of economically important floricultural crops based on visual inspection and microscopic observation carried out during 2017-18 in and around Jorhat district of Assam. During the investigation, 3 diseases of chrysanthemum ( 2 fungal, 1 viral); 3 diseases of gladiolus (all fungal); 5 diseases of gerbera (all fungal), 2 diseases of rose (all fungal) and a fungal disease of marigold was identified. The diseases identified in chrysanthemum were alternaria leaf spot, sooty mould and mosaic disease. The diseases identified in Gladiolus were fusarium infection, alternaria leaf spot, curvularia leaf spot and corm rot. The diseases identified in gerbera were alternaria leaf spot, cercospora leaf spot, damping off, stemphylium infection and coniothyrium infection. Diseases identified in rose were alternaria leaf spot and cercospora leaf spot. In marigold, alternaria leaf spot was indentified causing infection to the crop. Overall pathogenic disease incidence of flower crops recorded as $60.41 \%$ in Chrysanthemum, $45.83 \%$ in Gladiolus, $55.55 \%$ in gerbera, $47.22 \%$ in rose and $45.83 \%$ in marigold. Area wise maximum disease incidence $(61.11 \%)$ was observed in Borbheta area followed by Bahona( 58.33\%). Lowest disease incidence was recorded in Sungi (27.77\%) in Jorhat district.
\end{abstract}

Keywords: Disease incidence, floricultural crops, survey, pathogenic diseases, microscopic observation

\section{Introduction}

Floricultural crops are vital component of the horticultural industry in India. India has an ancient heritage of floriculture from time immemorial due to its extensive use in religious rituals and occasions. Thus significance to this sector is given for its diverse uses in different events of our life. Essential oil extracted from flowers is use for manufacturing of perfumes.

West Bengal, Karnataka, Maharashtra, Tamil Nadu, Odisha, Uttar Pradesh, Andhra Pradesh, Jammu and Kashmir and the North Eastern states are the major commercial flower growing states in India where marigold, roses, chrysanthemum, jasmine, tuberose etc. are commercially cultivated (Harisha et al., 2017). Floriculture industry is one of the most important commercial trades in horticulture as well as in Agriculture sector (Harisha et al., 2017). As the demand for cut flower in the market increases day by day in India growers emphasized on commercial export quality flower production. It is difficult to get good quality exportable blooms with higher yield and longer post harvest life of the cultivars under open conditions. Several factors have been found to be associated with this dwindling productivity of the flower crops. The most important factors associated are biotic and abiotic stresses. Among biotic stresses diseases caused by plant pathogens are prime factor.
Chrysanthemum (Chrysos, golden; anthos, flower) is a popular flower crop of commercial importance. It belongs to the family Composite and has been commonly grown in gardens for more than 2500 years (Bose et al., 2003). Intensive production during the first half of the twentieth century resulted in devastating diseases, such as those caused by the fungi Ascochyta, Septoria, and Verticillium, along with bacterial infections, root rots, rusts, and viral and viroid infections which severely threatened the chrysanthemum industry (Trolinger et al., 2017).

Gerbera (Gerbera jamesonii Bolus) is one of the beautiful cut flower being grown commercially under protected condition in Assam. It is considered a promising and valuable cut flower crop next to rose, ranks fifth among top ten cut flowers of world market (Saikia et al., 2018). In gerbera Powdery mildew, caused by Golovinomyces cichoracearum or Podosphaera sp., is the most common foliar disease of Gerbera daisies, but they are also plagued by Botrytis blight and Alternaria leaf spot. Gerbera is also susceptible to a host of root and crown rot diseases, including those caused by Fusarium, Phytophthora, and Pythium spp. (Brisco and Hausbeck, 2018).

Gladiolus (Gladiolus grandiflorus L.) belongs to the family Iridaceae and native to Europe, Mediterrenean region and South Africa. It is also known as queen of bulbous ornamental 
plants and sword lily. It has fascinating spikes that contains attractive, elegant, dazzling and delicate florets that open in sequence over longer duration and hence having good keeping quality for cut spikes. It is mainly used for garden, interior decoration and for making bouquets (Singh et al., 2014). In gladiolus Fusarium corm rot, Gladiolus rust, and Curvularia spot are the most limiting fungal diseases, whereas Cucumber mosaic virus and Bean yellow mosaic virus emerge as the more threatening viral diseases affecting gladiolus (Elmer and Kamo, 2018).

Rose is one of the natures beautiful creations and is universally acclaimed as the queen of flowers due to its variety of shapes, sizes, colours and versatility. It is certainly the best known and most popular of all garden flowers throughout the world and has been growing for many million years (Gault and Synge, 1971). The crop is attacked by a number of diseases. Rose black spot, caused by Diplocarpon rosae F.A. Wolf [imperfect stage-Marssonina rosae (Lib.) Lind.] is the most important disease of the rose worldwide (Baker, 1948; Baskaran and Ranganathan, 1974) except in regions of low seasonal rainfall. Dieback, powdery mildew, rust, stem blight, alternaria leaf spot and black spot are some of the important fungal diseases of rose (Kakade et al., 2006).

Marigold (Tagetes erecta L.) (Asteraceae) is a medicinal and ornamental plant. It is used for its nematocide, cosmetic and medicinal properties. The essential oil of the flower contains antioxidants (Perez Gutierrez et al., 2006). It is found in different colors and different fragrance. Yellow color is most common (Dixit et al., 2013). Alternaria spp., the cause of leaf spot and flower blight, and which are seed-and airborne in nature, are the major constraints in marigold cultivation (Chandel et al., 2010; Sen,1996; Qui et al., 2009).

Extremely limited information available about the prevalence of pathogenic diseases in flower crops of Assam. Therefore the study conducted to identify and record pathogenic diseases in some commercial flower crops in and around Jorhat district of Assam.

\section{Materials and Methods}

\subsection{Disease survey}

For present study, a few locations in and around Jorhat district were selected for the survey. The locations selected were Borbheta, Kenduguri, Bahona, Dhekiajuli, Sungi and Dergaon (Table 1 and 2). The diagnostic field survey was conducted during 2017-2018 in selected localities in order to find out the status of disease incidence in commercial flower crops. For sampling purposes, within a field a roving survey was conducted following a zig-zag sampling pattern each of the fields. Nearly 6 plants plot $^{-1}$ were selected randomly and observations were made as \% incidence of diseases. Plant samples were taken to the laboratory and pathogens were confirmed using compound microscope. For different diseases incidence was estimated as a $\%$ age of individual plants expressing symptoms of a disease within the field section. Thus, \% disease incidence was calculated in all the six locations surveyed along with disease incidence in all five flower crops that were considered for the study (Table 1 and 2).

Percent disease incidence $=($ No. of infected plants $/$ Total number of plants) $\times 100$

\subsection{Symptomatology and microscopic study of the pathogen}

Symptoms of different diseases of flower crops were studied in the field and laboratory condition. Sampling survey conducted in different areas aided in observing symptom development in the plant and microscopic study of the pathogen done in laboratory condition. Collected samples of the diseased plants were stored in moist condition for further microscopic study. The microscopic observation of the pathogens was done through light microscope. Morphological characters of the fungal pathogens were studied viz., type of mycelium, branching pattern, type of spores, their shape and presence of sexual structures of the pathogen (Table 3). Microphotographs of the pathogen were taken.

\section{Results and Discussion}

\subsection{Disease survey}

In this study, overall pathogenic disease incidence of flower crops recorded as $60.41 \%$ in Chrysanthemum, $45.83 \%$ in Gladiolus, $55.55 \%$ in gerbera , $47.22 \%$ in rose and $45.83 \%$ in marigold (Table 1). It was found that the Alternaria leaf blight disease was found to be more severe in surveyed areas followed by cercospora leaf spot. Area wise maximum disease incidence (61.11\%) was observed in Borbheta area followed by Bahona( $58.33 \%)$. Lowest disease incidence was recorded in Sungi ( $27.77 \%$ ) (Table 2). Data presented in Table 1, shows the incidence of different pathogenic diseases in flower crops of Jorhat, Assam. The details of the results obtained are presented below:

\subsection{Symptomatology and identification of pathogen of surveyed crops}

\subsubsection{Chrysanthemum}

a) Alternaria blight: Symptoms consisted of spots on the leaves as well as on petals. These spots were at first yellowish, and then became dark brown and black surrounded by yellow halo. Later defoliation of leaves occured and plant died (Figure 1). The causal organism of the disease was Alternaria spp. The fungus produce muriform conidia having both transverse and longitudinal septa. Conidia observed under microscope attached in the conidiophores in chain. Conidia and conidiophores were coloured (Figure 2) (Table $3)$. The results were in conformity with the study of Kumar et al. (2011), Trolinger et al. (2018), Dominguez-Serrano et al. (2016), Farhood and Shervin (2019).

b) Sooty mould: Black superficial fungal growth on the aerial parts of plants were observed particularly on upper leaf 


\begin{tabular}{|c|c|c|c|c|c|c|}
\hline $\begin{array}{l}\text { Sl. } \\
\text { No. }\end{array}$ & Flower crops & Pockets & $\begin{array}{l}\text { Geographic location of } \\
\text { the area }\end{array}$ & $\begin{array}{l}\text { Infected plants } \\
\text { (total plants surveyed) }\end{array}$ & $\begin{array}{c}\text { Disease } \\
\text { incidence (\%) }\end{array}$ & Disease observed \\
\hline \multirow[t]{8}{*}{1.} & \multirow[t]{8}{*}{ Chrysanthemum } & 1. Borbheta & $26^{\circ} 44^{\prime} \mathrm{N}, 94010^{\prime} \mathrm{E}$ & $4(6)$ & \multirow{8}{*}{$29 \div 48=60.41$} & \multirow{5}{*}{$\begin{array}{c}\text { 1.Aternaria leaf } \\
\text { blight }\end{array}$} \\
\hline & & 2. Kenduguri & $26.7690^{\circ} \mathrm{N}, 94.2371^{\circ} \mathrm{E}$ & $5(6)$ & & \\
\hline & & 3. Bahona & $30.7823^{\circ} \mathrm{N}, 75.2056^{\circ} \mathrm{E}$ & $4(6)$ & & \\
\hline & & 4. Dhekiajuli & $26.6985^{\circ} \mathrm{N}, 92.4851^{\circ} \mathrm{E}$ & $2(6)$ & & \\
\hline & & 5. Dergaon & $26.7^{\circ} \mathrm{N}, 93.97^{\circ} \mathrm{E}$ & $4(6)$ & & \\
\hline & & 1. Borbheta & $26^{\circ} 44^{\prime} \mathrm{N}, 94^{\circ} 10^{\prime}$ & $3(6)$ & & \multirow[t]{2}{*}{ 2. Sooty mould } \\
\hline & & 2. Bahona & $30.7823^{\circ} \mathrm{N}, 75.2056^{\circ} \mathrm{E}$ & $2(6)$ & & \\
\hline & & 1. Borbheta & $26^{\circ} 44^{\prime} \mathrm{N}, 94^{\circ} 10^{\prime}$ & $5(6)$ & & $\begin{array}{l}\text { 3.Mosaic of } \\
\text { chrysanthemum }\end{array}$ \\
\hline \multirow[t]{8}{*}{2.} & \multirow[t]{8}{*}{ Gladiolus } & 1. Dergaon & $26.7^{\circ} \mathrm{N}, 93.97^{\circ} \mathrm{E}$ & $2(6)$ & \multirow[t]{8}{*}{$22 \div 48=45.83$} & 1.Fusarium yel- \\
\hline & & 2. Borbheta & $26^{\circ} 44^{\prime} \mathrm{N}, 94^{\circ} 10^{\prime}$ & $5(6)$ & & low \\
\hline & & 1. Borbheta & $226.6985^{\circ} \mathrm{N}, 92.4851^{\circ} \mathrm{E}$ & $3(6)$ & & 2.Alternaria \\
\hline & & 2. Dhekiajuli & $26044^{\prime} \mathrm{N}, 94^{\circ} 10^{\prime}$ & $2(6)$ & & Blight \\
\hline & & 3. Sungi & $26.6134^{\circ} \mathrm{N}, 93.8318^{\circ} \mathrm{E}$ & $2(6)$ & & \\
\hline & & 4. Degaon & $26.7^{\circ} \mathrm{N}, 93.97^{\circ} \mathrm{E}$ & $3(6)$ & & \\
\hline & & 1. Borbheta & $26^{\circ} 44^{\prime} \mathrm{N}, 94^{\circ} 10^{\prime}$ & $2(6)$ & & 3.Curvularia leaf \\
\hline & & 2. Kenduguri & $26.7690^{\circ} \mathrm{N}, 94.2371^{\circ} \mathrm{E}$ & $3(6)$ & & spot \\
\hline \multirow[t]{12}{*}{3.} & \multirow[t]{12}{*}{ Gerbera } & 1. Borbheta & $26^{\circ} 44^{\prime} \mathrm{N}, 94^{\circ} 10^{\prime}$ & $6(6)$ & \multirow[t]{12}{*}{$40 \div 72=55.55$} & 1.Alternaria leaf \\
\hline & & 2. Kenduguri & $26.7690^{\circ} \mathrm{N}, 94.2371^{\circ} \mathrm{E}$ & $4(6)$ & & spot \\
\hline & & 3. Dhekiajuli & $26.6985^{\circ} \mathrm{N}, 92.4851^{\circ} \mathrm{E}$ & $2(6)$ & & \\
\hline & & 4. Bahona & $30.7823^{\circ} \mathrm{N}, 75.2056^{\circ} \mathrm{E}$ & $5(6)$ & & \\
\hline & & 5. Sungi & $26.6134^{\circ} \mathrm{N}, 93.8318^{\circ} \mathrm{E}$ & $2(6)$ & & \\
\hline & & 6. Dergaon & $26.7^{\circ} \mathrm{N}, 93.97^{\circ} \mathrm{E}$ & $2(6)$ & & \\
\hline & & 1. Kenduguri & $26.7690^{\circ} \mathrm{N}, 94.2371^{\circ} \mathrm{E}$ & $2(6)$ & & 2. Rhizoctonia rot \\
\hline & & 2. Bahona & $30.7823^{\circ} \mathrm{N}, 75.2056^{\circ} \mathrm{E}$ & $2(6)$ & & \\
\hline & & 1. Borbheta & $26^{\circ} 44^{\prime} \mathrm{N}, 94^{\circ} 10^{\prime}$ & $3(6)$ & & 3.Cercospora leaf \\
\hline & & 2. Kenduguri & $26.7690^{\circ} \mathrm{N}, 94.2371^{\circ} \mathrm{E}$ & $2(6)$ & & spot \\
\hline & & 3. Dergaon & $26.7^{\circ} \mathrm{N} 93.97^{\circ} \mathrm{E}$ & $3(6)$ & & \\
\hline & & 1. Borbheta & $26^{\circ} 44^{\prime} \mathrm{N}, 94^{\circ} 10^{\prime}$ & $4(6)$ & & $\begin{array}{l}\text { 4.Stemphyllum } \\
\text { and coniothyrium } \\
\text { infection }\end{array}$ \\
\hline \multirow[t]{6}{*}{4.} & \multirow[t]{6}{*}{ Rose } & 1. Borbheta & $26^{\circ} 44^{\prime} \mathrm{N}, 94^{\circ} 10^{\prime}$ & $4(6)$ & \multirow[t]{6}{*}{$17 \div 36=47.22$} & 1.Alternaria leaf \\
\hline & & 2. Kenduguri & $26.7690^{\circ} \mathrm{N}, 94.23710 \mathrm{E}$ & $3(6)$ & & spot \\
\hline & & 3. Sungi & $26.6134^{\circ} \mathrm{N}, 93.8318^{\circ} \mathrm{E}$ & $1(6)$ & & \\
\hline & & 4. Bahona & $30.7823^{\circ} \mathrm{N}, 75.2056^{\circ} \mathrm{E}$ & $4(6)$ & & \\
\hline & & 1. Borbheta & $26^{\circ} 44^{\prime} \mathrm{N}, 94^{\circ} 10^{\prime}$ & $3(6)$ & & 2,Cercospora leaf \\
\hline & & 2. Kenduguri & $26.7690^{\circ} \mathrm{N}, 94.2371^{\circ} \mathrm{E}$ & $2(6)$ & & spot \\
\hline \multirow[t]{4}{*}{5.} & \multirow[t]{4}{*}{ Marigold } & 1. Borbheta & $26^{\circ} 44^{\prime} \mathrm{N}, 94^{\circ} 10^{\prime}$ & $2(6)$ & \multirow[t]{4}{*}{$11 \div 24=45.83$} & \multirow{4}{*}{$\begin{array}{c}\text { 1.Alternaria leaf } \\
\text { spot }\end{array}$} \\
\hline & & 2. Kenduguri & $26.7690^{\circ} \mathrm{N}, 94.2371^{\circ} \mathrm{E}$ & $2(6)$ & & \\
\hline & & 3. Bahona & $30.7823^{\circ} \mathrm{N}, 75.2056^{\circ} \mathrm{E}$ & $4(6)$ & & \\
\hline & & 4. Dergaon & $26.7^{\circ} \mathrm{N}, 93.97^{\circ} \mathrm{E}$ & $3(6)$ & & \\
\hline
\end{tabular}

surface of the leaves (Figure 3). The disease was caused by Cladosporium spp. The fruiting body of the fungus observed under microscope which resembled perithecia (Figure 4) (Table3). The results were in conformity with the study of 
Table 2: Disease incidence of floricultural crops in different pockets of Jorhat district

\begin{tabular}{lcc}
\hline SI. No. & Location & Disease incidence (\%) \\
\hline 1. & Borbheta & 61.11 \\
2. & Kenduguri & 47.91 \\
3. & Bahona & 58.33 \\
4. & Dergaon & 50.00 \\
5. & Sungi & 27.77 \\
6. & Dhekiajuli & 33.33 \\
\hline
\end{tabular}

Chomnunti et al. (2014).

c) Mosaic of chrysanthemum: Infected plant has shown stunted growth. The leaves of infected plants were deformed, small and leathery and exhibit mosaic and mottling with raised dark green areas. Blisters were formed on the leaves and size of leaves reduced (Figure 5).The aphid vector of the viral disease was is also observed in some of the surveyed locations. The mosaic virus infection was confirmed by sap inoculation assay (Figure 6) . The results were in conformity with the study of Keller (1950) and Noordam (1952).

\subsubsection{Gerbera}

a) Cercospora leaf spot: Small round water soaked lesions developed on leaves and stems. Later those spots coalesced and blighted the entire leaf (Figure 7). Cercospora spp. cause Cercospora leaf spot disease of gerbera. The conidiophores of the fungus geniculat type, septate, dark coloured. Conidia were observed as septate and needle shaped (Figure 8) (Table $3)$. The results were in conformity with the study of Singh and Kumar (2012).

b) Stemphylium and coniothyrium infection: Necrotic lesions were coalesce to form large canker like area on leaf (Figure 9). Coniothyrium pycnidia observed with pycniospores (Figure 10). Spores emerging from pycnidia were observed under microscope (Figure 11) (Table 3). Stemphylium spore were single oval, muriform, constricted at central septum (Figure 11) (Table 3). The results were in conformity with Nishi et al. (2009).

c) Alternaria leaf spot: Characteristic symptom leaf spots with concentric rings observed on infected leaves. The spots were mostly irregular and coalesce to cover large areas of the leaf blade. Brown specks form on florets and the leaves. Centers

Table 3: Microscopic study of the fungal pathogens associated with the diseases of floricultural crops

Fungal Pathogen Microscopic observation and confirmation

Alternaria spp. In chrysanthemum, the fungus Alternaria spp produced muriform conidia having both transverse and longitudinal septa which were attached in the conidiophores in chain. Conidia and conidiophores produced by the fungus were coloured (Figure 2).

In gerbera, Fungal pathogen Alternaria alternata produced obclavate conidia with short beak at tip . Conidia was having both transverse and longitudinal septa, conidia were coloured (Figure 13).

In gladiolus, The conidia were coloured, obclavate having both longitudinal and transverse septa on it (Figure 20).

In rose, The Conidia of the fungus Alternaria spp are coloured, obclavate having both longitudinal and transverse septa and they were attached with conidiophores on chain (Figure 24).

In marigold, The conidia were coloured, obclavate having both longitudinal and transverse septa and it was attached to the conidiopohore in chain (Figure 28).

Sooty mould The fruiting body of Cladosporium spp in chrysanthemum, were observed which were resembling perithecia (Figure 4).

Cercospora spp. In gerbera, the conidiophores of the fungus Cercospora spp are geniculat type, septate and dark in colour. Conidia were observed septate and needle shaped (Figure 8).

In rose, truft of Conidiophores of the fungus Cercospora spp were developed from stoma. The conidia were cylindrical and having septa on it (Figure 26).

Stemphyllum In gerbera, pycnidia of the Coniothyrium spp were observed with pycniospores (Figure 10). Spores spp. and Conio- emerging from pycnidia are observed under microscope (Figure 11).

thyrium spp. Spores of Stemphyllum spp were observed as single oval, muriform, constricted at central septum (Figure 11).

Rhizoctonia spp. In gerbera, hyphae of the pathogen Rhizoctonia spp were showing the distinguishing right angles with constriction at the point of swelling .Hyphae of the fungus were septate (Figure 15).

Fusarium spp. In gladiolus, Sickle shaped macroconidia of Fusarium spp observed under the microscope (Figure 18). Conidia of the fungus were septate and coloured.

Curvularia spp. In gladiolus, the conidiophores of Curvularia spp were geniculate, conidia were ellipsoidal, curved, rounded at end. Conidia tapering slightly at ends (Figure 22). 


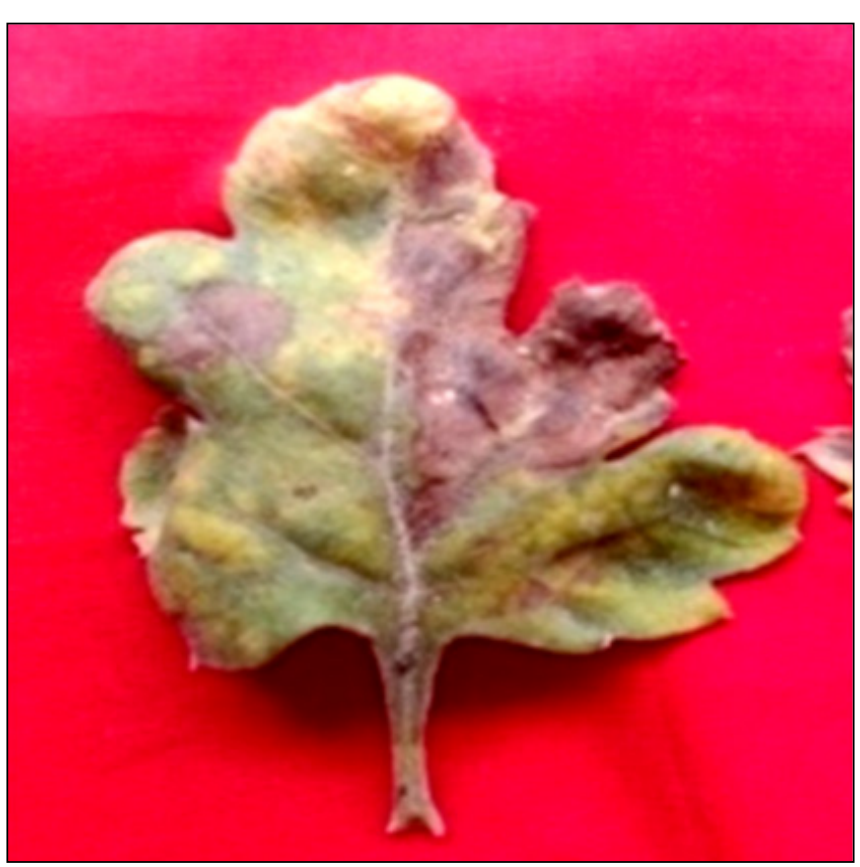

Figure 1: Alternaria leaf blight of Chrysanthemum

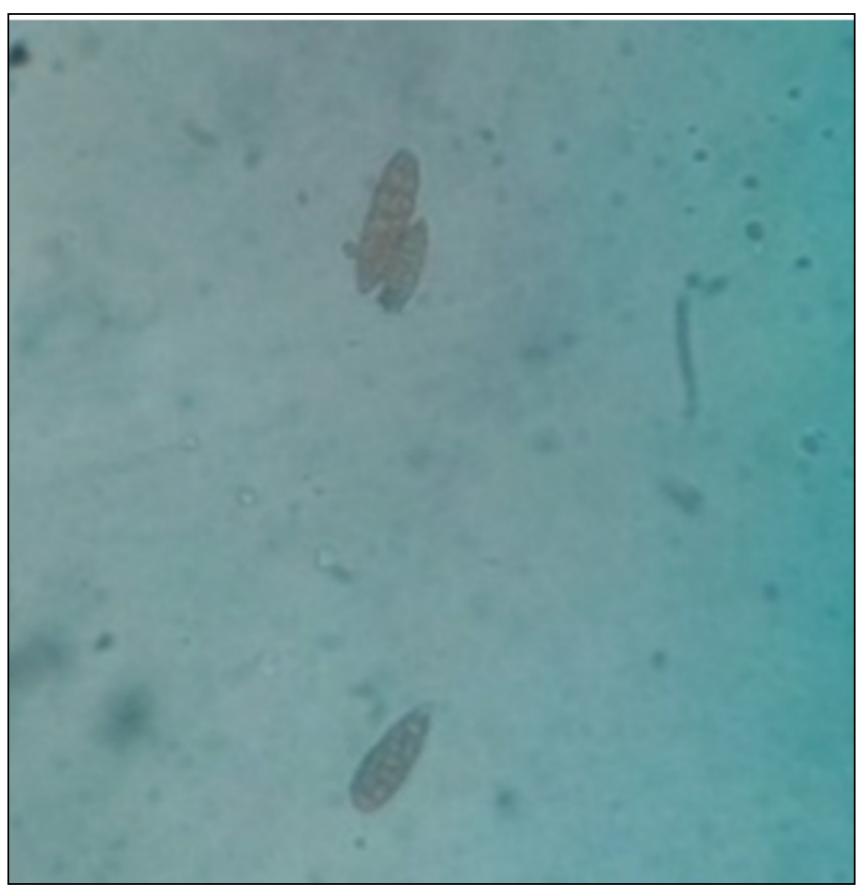

Figure 2: Alternaria spp. Causing leaf blight of chrysanthemum

became white on the leaf spots (Figure 12). Fungal pathogen Alternaria alternate cause Alternaria leaf spot of Gerbera . Under the microscope we observed obclavate conidia with short beak at tip. Conidia had 2 transverse and 8 longitudinal septa, conidia were colored (Figure 13) (Table3). The results were in conformity with the study of Farhood and Hadian (2019).

d) Rhizoctonia rot: Symptom consisted of blackening of the petiole of leaves at the base as the plant. Later the infected

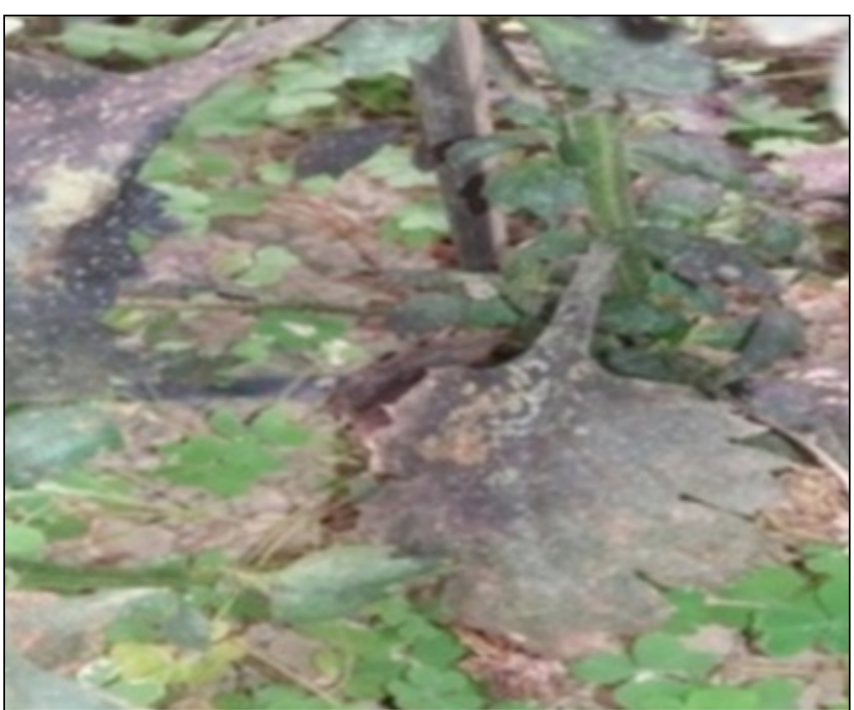

Figure 3: Sooty mould of Chrysanthemum

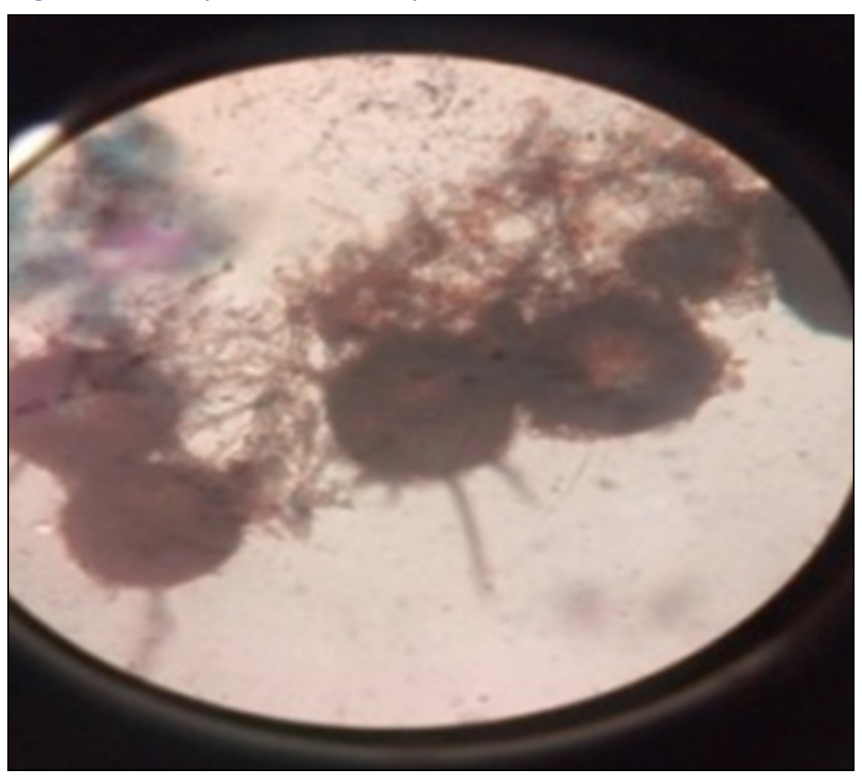

Figure 4: Microscopic features of Cladosporium spp causing sooty mould of chrysanthemum

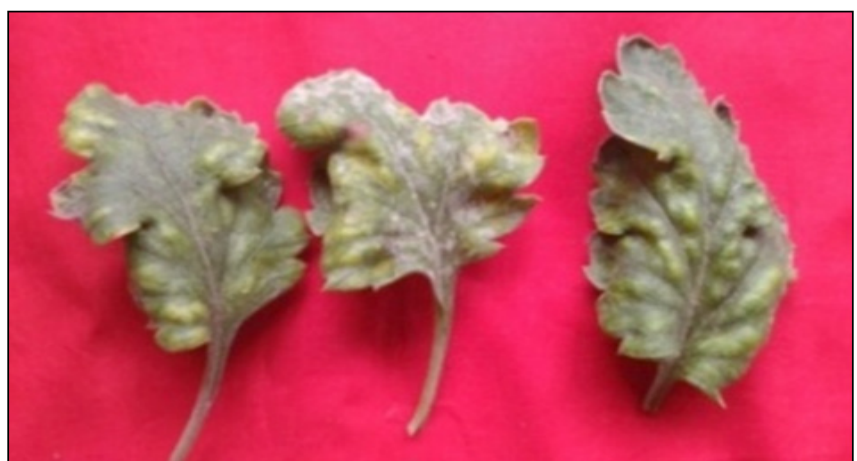

Figure 5: Mosaic and mottled leaf of chrysanthemum due to virus infection

plants collapsed (Figure 14).Causal organism of the disease was Rhizoctonia spp. Hyphae of the pathogen showing the 


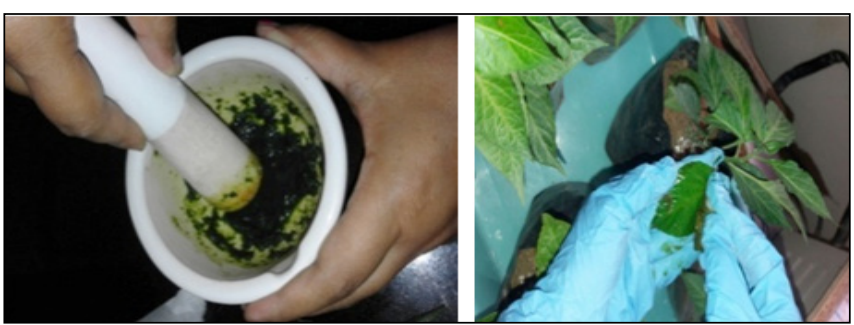

Figure 6: Sap inoculation assay of plant virus in chrysanthemum

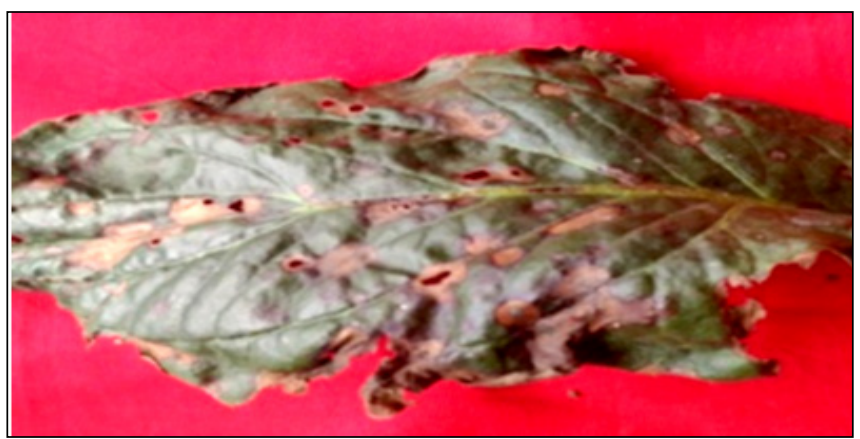

Figure 7: Cercospora leaf spot of gerbera

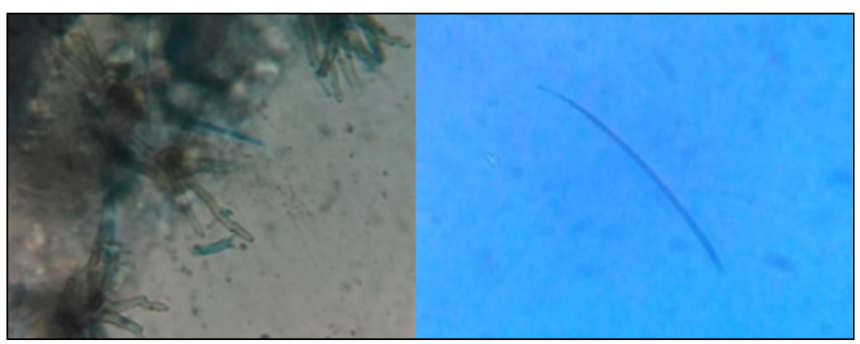

Figure 8: Conidiophore and conidia of cercospora spp in gerbera

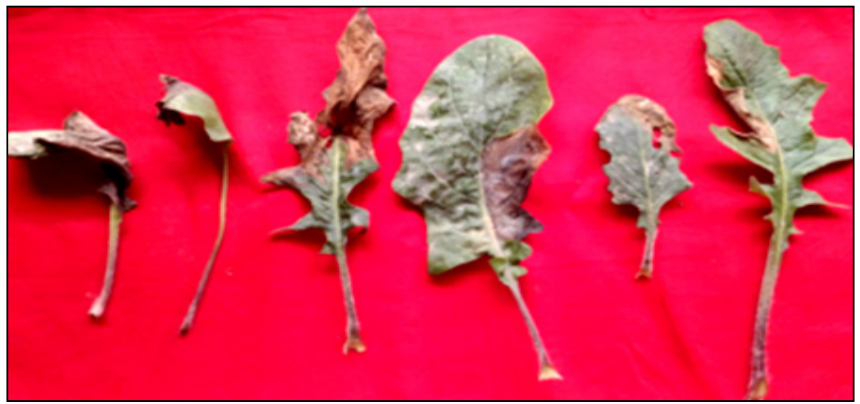

Figure 9: Stemphylium and coniothyrium infection in gerbera

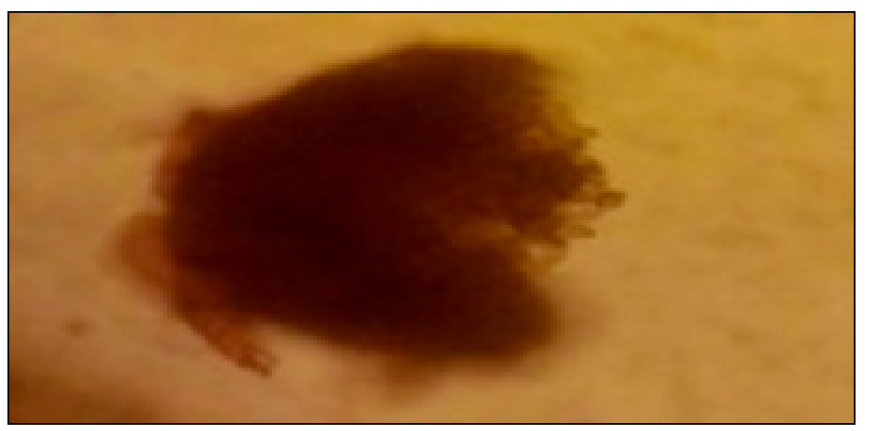

Figure 10: Coniothyrium ascus with ascospore (spores emerge from pycnidia) in gerbera

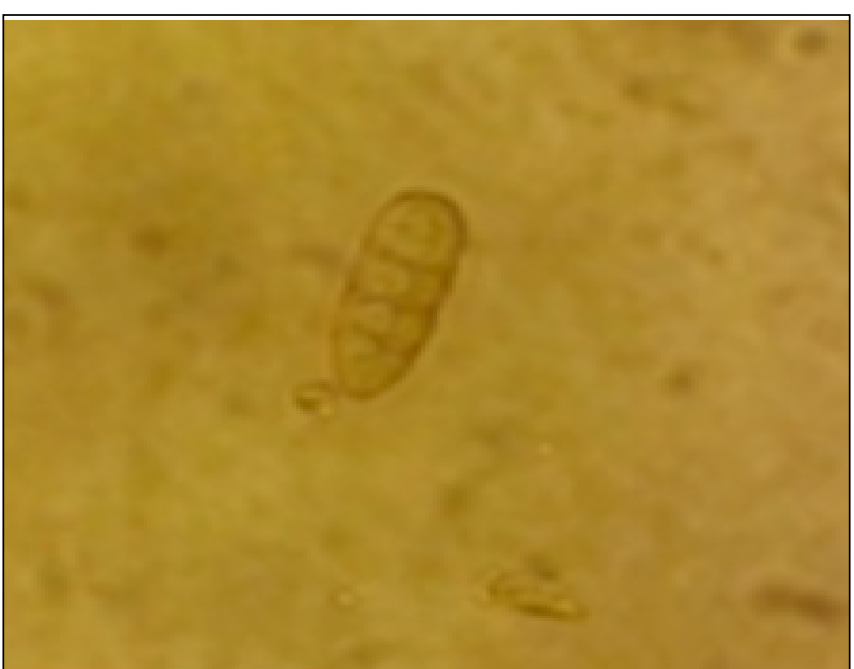

Figure 11: Stemphylium spore in gerbera

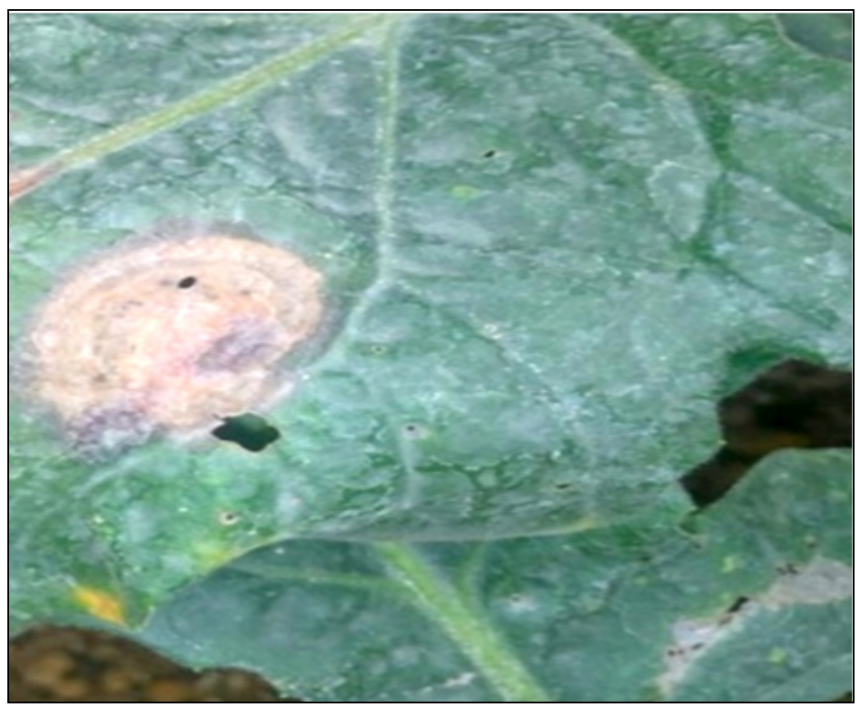

Figure 12: Alternaria leaf spot of gerbera

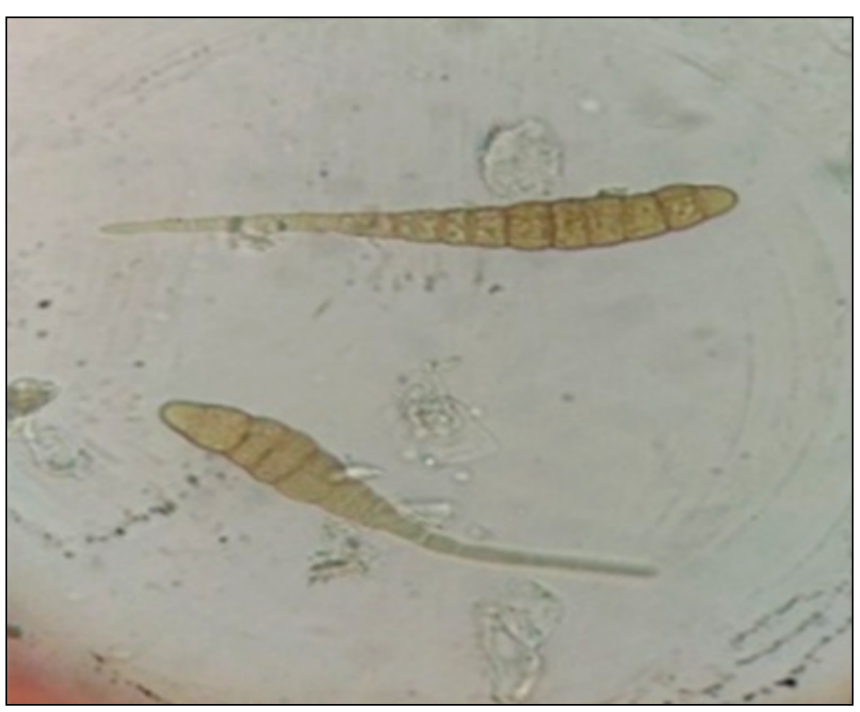

Figure 13: Alternaria spp spore in gerbera 


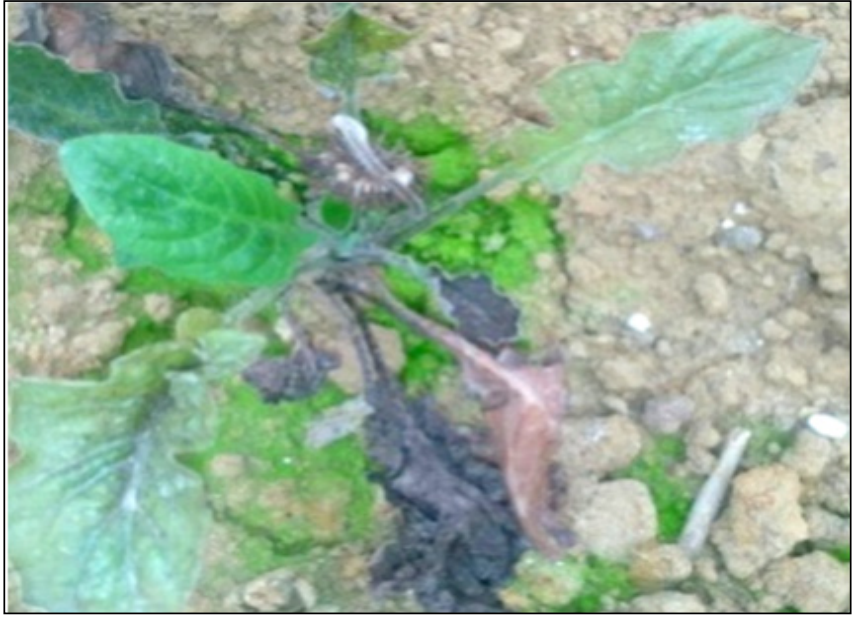

Figure 14: Rhizoctonia rot of gerbera

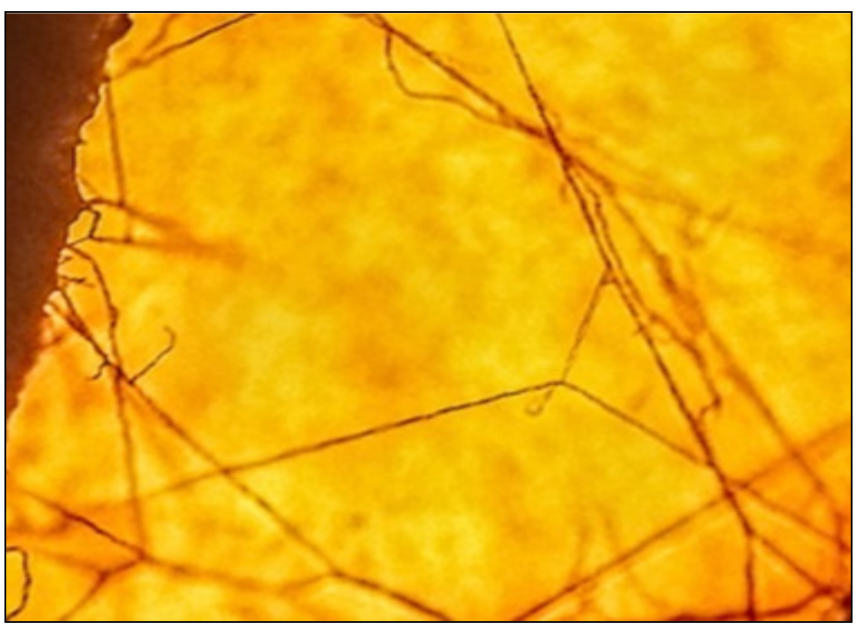

Figure 15: Mycelia of Rhizoctonia sp under microscope producing right angles

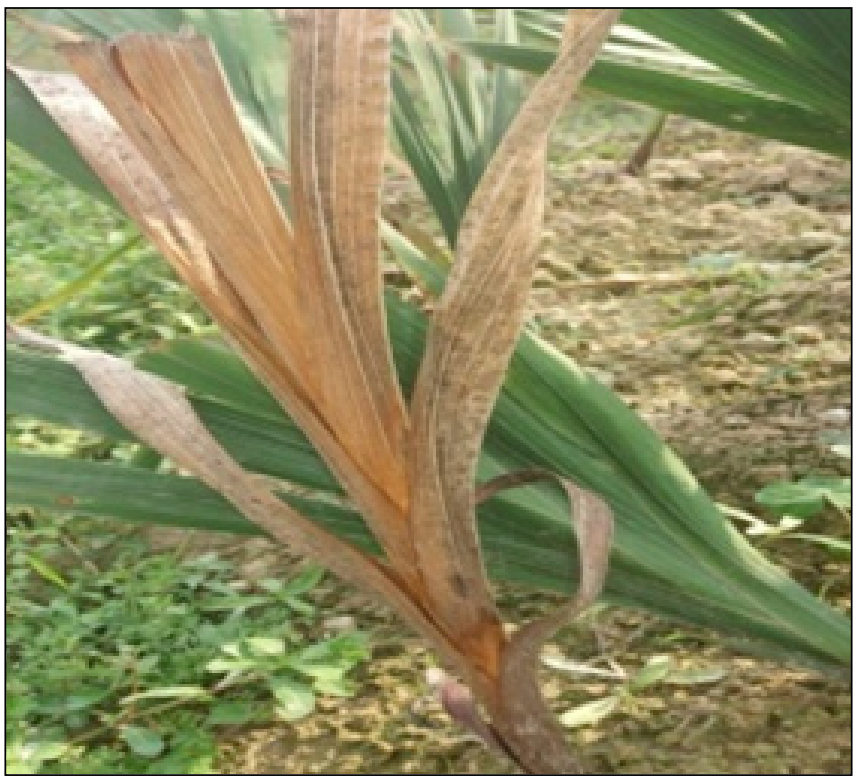

Figure 16: Fusarium infection in gladiolus

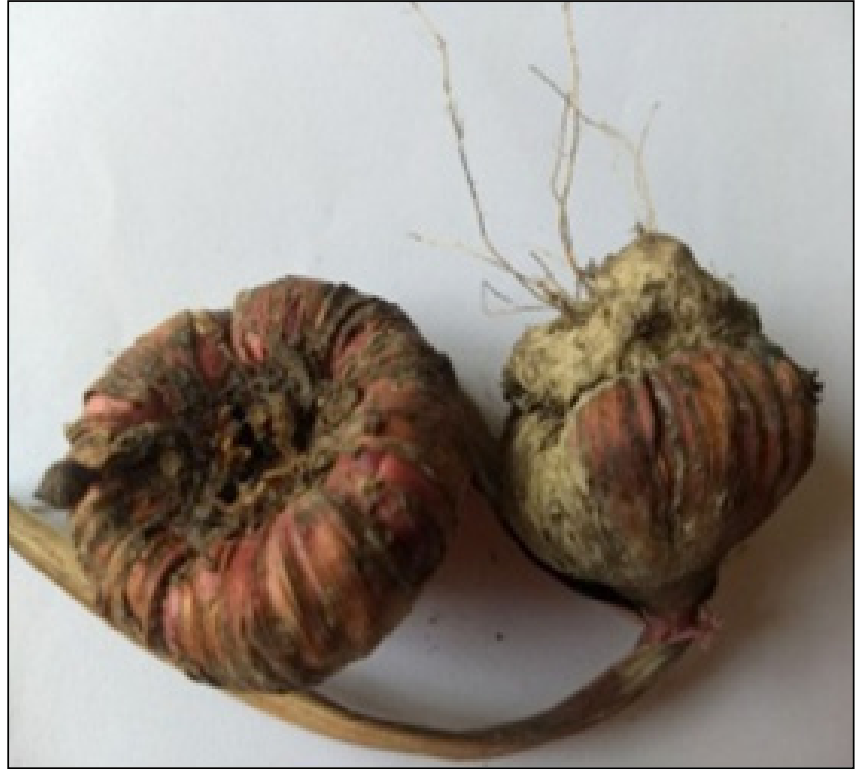

Figure 17: Fusarium infection in gladiolus corms

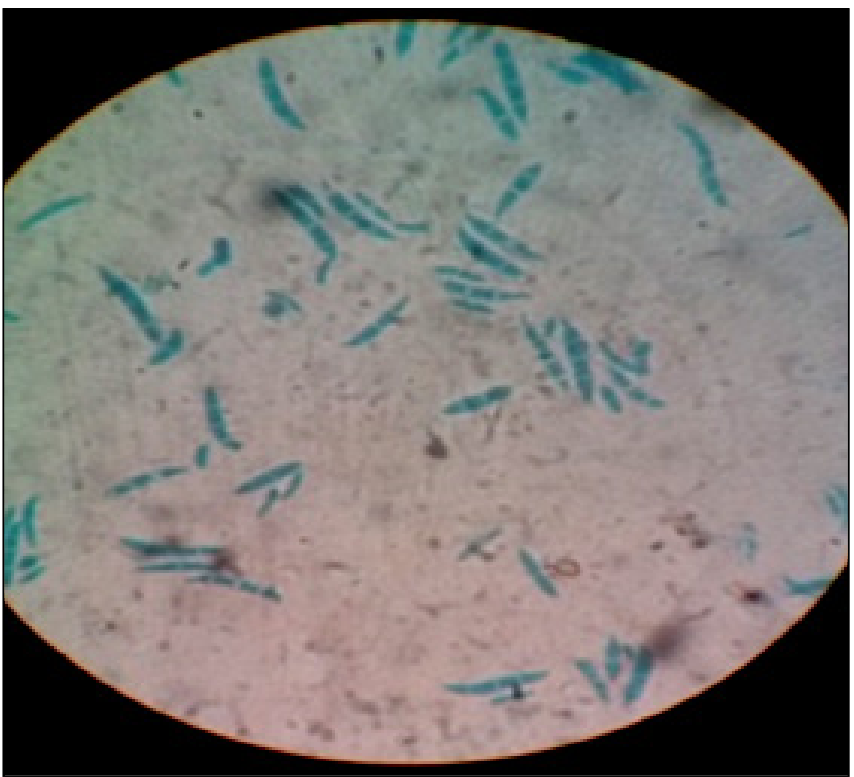

Figure 18: Sickle shaped macroconidia of Fusarium spp in infected gladiolus plant

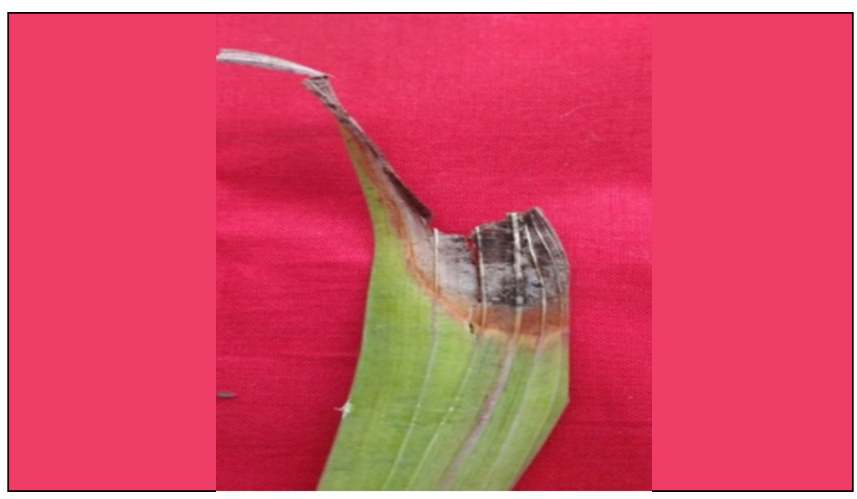

Figure 19: Leaf spot of gladiolus caused by Alternaria spp 


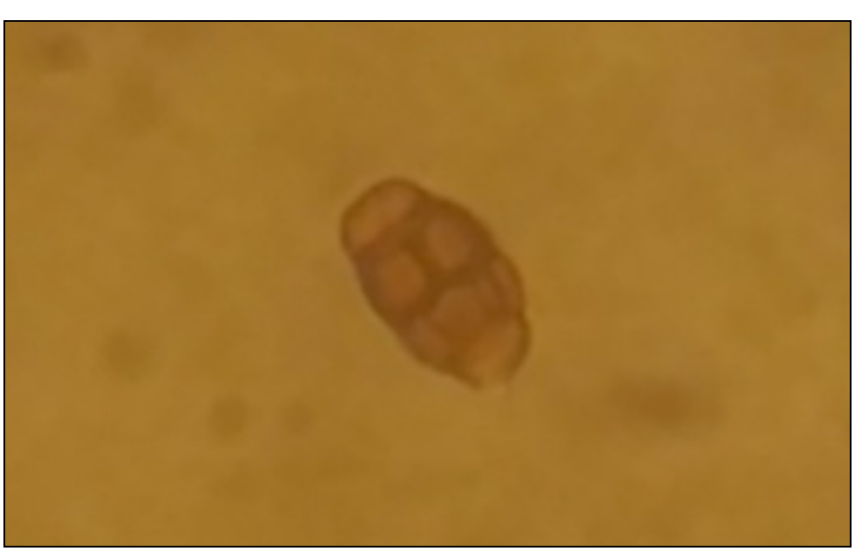

Figure 20: Conidia of Alternaria spp from indected gladiolus leaf

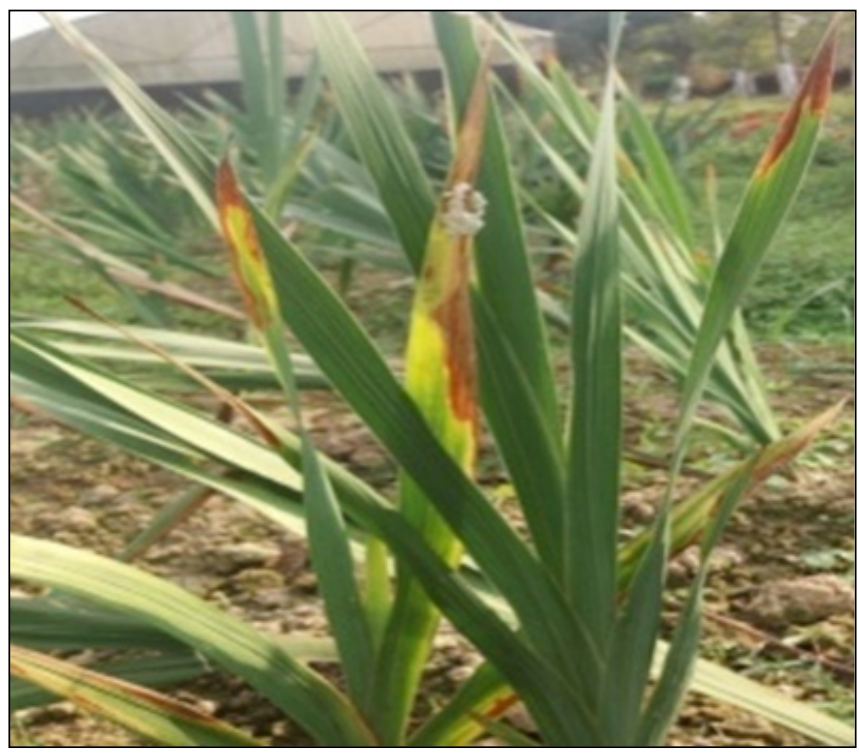

Figure 21: Curvularia leaf spot of gladiolus

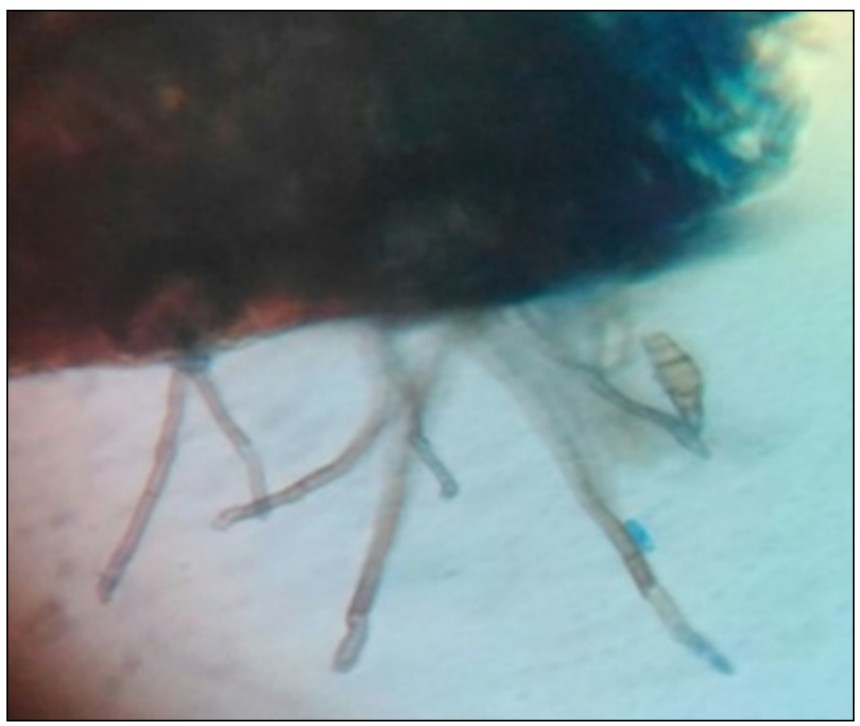

Figure 22: Conidiophores and conidia of cuvularia spp from infected gladiolus leaf

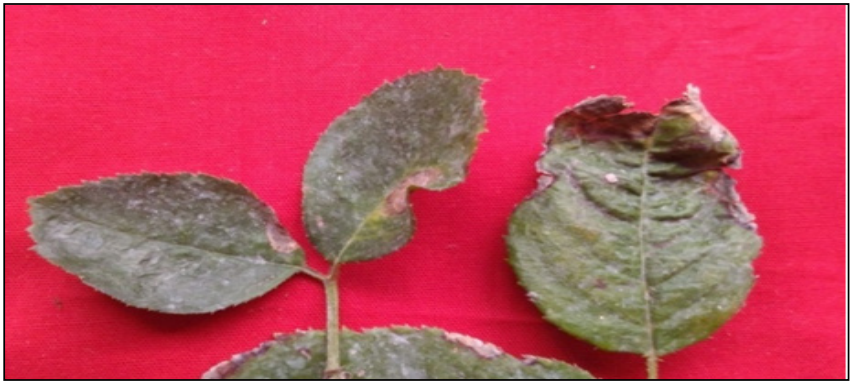

Figure 23: Alternaria leaf spot of rose

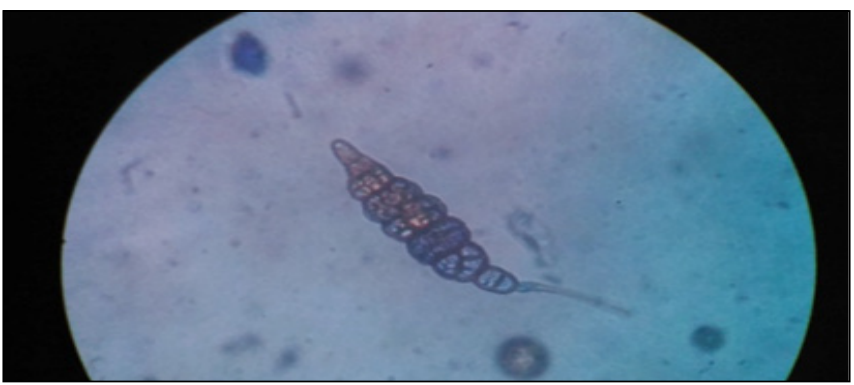

Figure 24: Alternaria spp. Conidia observed from infected rose leaves

distinguishing right angles and had constriction at the point of swelling .Hyphae were septate(Figure 15) (Table 3). The results were in conformity with the study of Wick and Dicklow (2013).

\subsubsection{Gladiolus}

a) Fusarium yellow: Older leaves became yellow and stunted growth of plants observed. Flower size, shape and color became abnormal. Flowers not developed while stalks were curved. Corms rotted from the center outward. Oval, sunken spots on the corm surface were brown and had concentric rings. Centre of the corm turned black and rotted completely (Figure 16, 17). Pathogen Fusarium spp cause fusarium yellow of gladiolus. Under the microscope sickle shaped macroconidia, were observed (Figure 18) (Table3). Conidia of the fungus were septate and coloured. The results were in conformity with the study of Riaz et al. (2010).

b) Alternaria Blight: The most pronounced symptom brownish circular spot with yellow margins was observed on leaves, later spot coalescing and cover large area of plant (Figure 19). Alternaria blight of gladiolus caused by Alternaria spp. The conidia were observed under miocroscope as coloured, obclavate having both longitudinal and transverse septa on it (Figure 20) (Table3). The results were in conformity with the study of Bhagat et al. (2018).

c) Curvularia leaf spot: Symptom consisted of brown colour oval to circular spot surrounded by yellow halo. Later the spot emerged and necrotic lesions were observed on leaves (Figure 21). Casual organism of the disease was Curularia spp. The conidiophores were geniculate, Conidia were ellipsoidal, often curved, rounded at end. Conidia tapering slightly at ends (Figure 22) (Table 3). The results were in conformity with the 
study of Torres et al. (2013), Riaz et al. (2010).

\subsubsection{Rose}

a) Alternaria leaf spot: Characteristic leaf spot symptom with concentric ring were observed on leaves. The spots were mostly irregular and coalesce to cover large areas of the leaf blade. Small dark circular spots with light brown centers surrounded by concentric ring (Figure 23). The Causal organism was identified as Alternaria spp. through microscopic observation. The Conidia were observed as coloured, obclavate having both longitudinal and transverse septa and they attached with conidiophores on chain (Figure 24) (Table 3). The results were in conformity with the study of Abbas et al. (2017).

b) Cercospora leaf spot: Circular spots appeared on leaf later coalesced to form large necrotic area (Figure 25). The disease was caused by Cercospora spp. Truft of Conidiophores developed from stoma. The conidia were observed under microscope as cylindrical and having septa (Figure 26) (Table $3)$. The results were in conformity with the study of Kang et al. (2019).

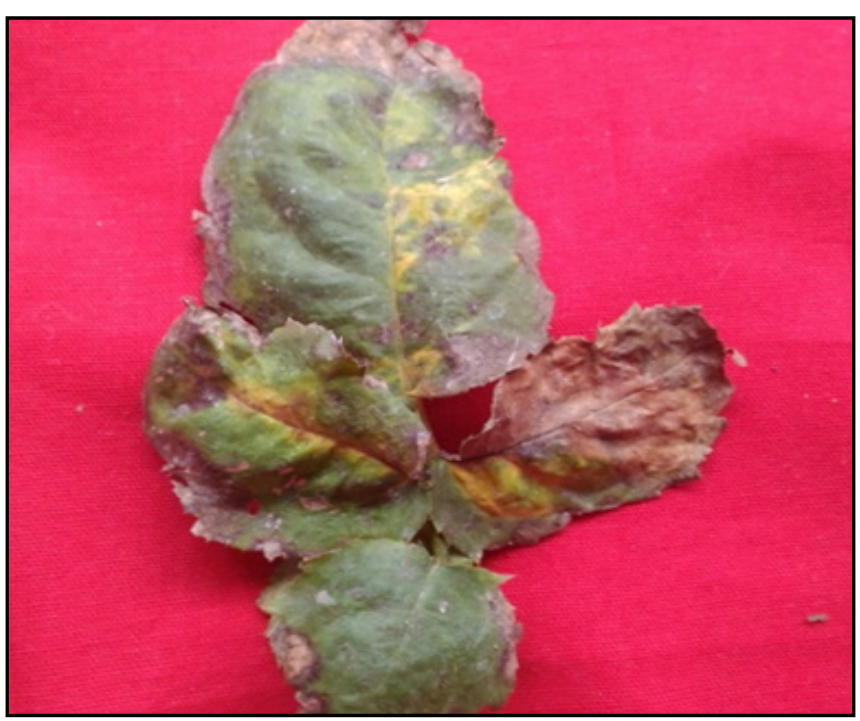

Figure 25: Cercospora leaf spot of rose

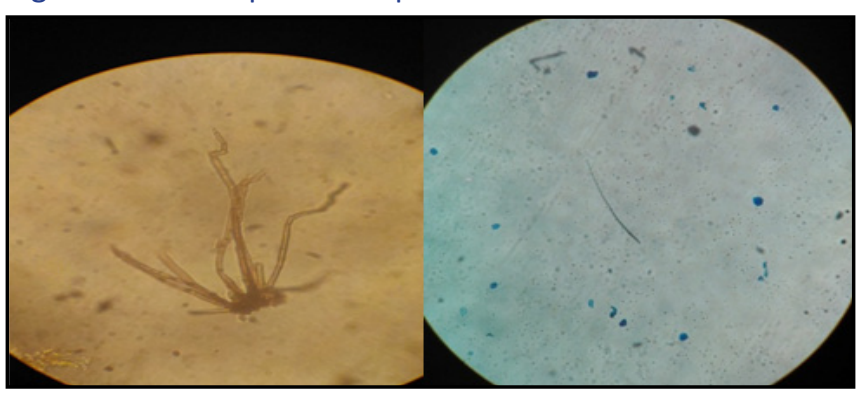

Figure 26: Conidia and conidiophores of Cercospora spp. Observed from infected rose leaves

\subsubsection{Marigold}

a) Alternaria leaf spot: The first symptom observed as circular brownish spot on leaf. Later the spots turned blackish, coalesced and it covered entire leaf and reduced the flower quality (Figure 27). The Causal organism of the disease was identified as Alternaria alternata. The conidia were coloured and obclavate. The conidia having both longitudinal and transverse septa and its attached to the conidiopohore in chain (Figure 28) (Table 3). The results were in conformity with the study of Tomioka et al. (2000) and Hotchkiss and Baxter (1983).

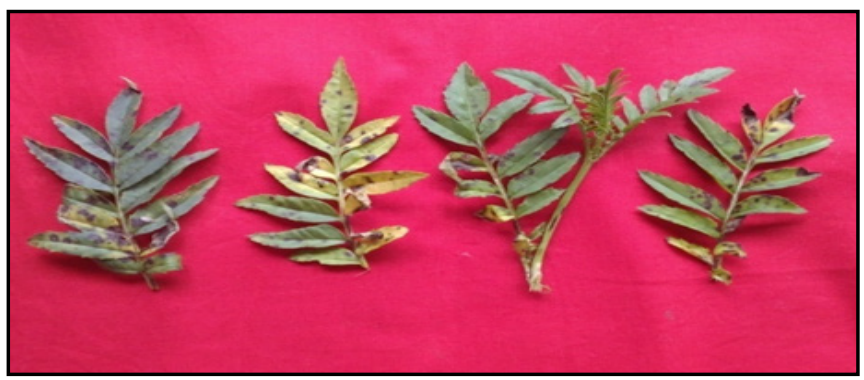

Figure 27: Alternaria leaf spot of marigold

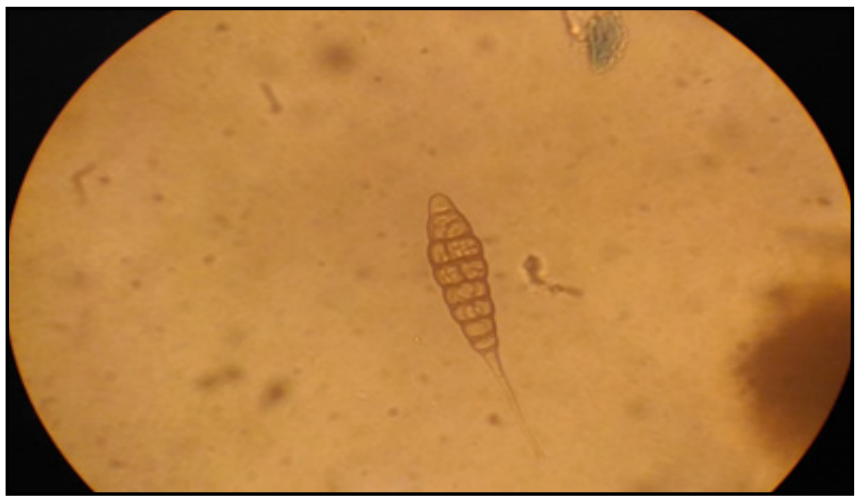

Figure 28: Alternaria spp. Conidia observed from infected marigold leaves

\section{Conclusion}

After carrying out the survey for disease incidence in floricultural crops of Jorhat district an nearby areas, we could draw the conclusions that most of the floricultural crops found to be disease stressed. Management of diseases is based upon identification of the diseases to take up management strategies. Recognition and control of these diseases is vital and therefore this research will help increase the current understanding for growers and researchers on identification and determining disease incidence levels in field.

\section{References}

Abbas, M.F., Aziz-ud-Din, R.K., Rafique, K., Qadir, A., Rashid, A., Qamar, M.I., Gleason, M.L., 2017. First Report of Alternaria Black Spot of Rose Caused by Alternaria alternata in Pakistan. Plant Disease 101(9), 1676-1677.

Baker, K. F., 1948. The history, distribution and nomenclature of the Rose black spot fungus. Plant Disease Reporter 32, 260-274.

Bhagat, S.S., Ingle, S.T., Gupta, V., 2018. Study on isolation, purification and identification of gladiolus disease. 
International Journal of Chemical Studies 6, 1554-1558.

Bhaskaran, R., Purushothaman, D., Ranganathan, K., 1974. Physiological changes in rose leaves infected by Diplocarpon rosae. Journal of Phytopathology 79(3), 231-236.

Bose, T.K., Yadav, L.P., Pal ,P., Pathasarathy, V.A., Das, P., 2003. Chrysanthemum Commercial Flowers. Vol-1. 2nd Rev. ed. Nayaprokash, Calcutta, India, 463-602.

Brisco-McCann, E.I., Hausbeck, M.K., 2018. Diseases of Gerbera. In: McGovern, R., Elmer, W. (Eds), Handbook of Florists' Crops Diseases. Handbook of Plant Disease Management. Springer, Cham, 533-559.

Chandel, S., da Silva, J.A.T., Sharma, C., 2010. Management of Alternaria Leaf Spot and Flower Blight of Marigold (Tagetes erecta L.) cv. 'Crackerjack'by Applications of Fungicides and Neem Formulation. Floriculture and Ornamental Biotechnology 4, 79-83.

Chomnunti, P., Hongsanan, S., Aguirre-Hudson, B., Tian, Q., Persoh, D., Dhami, M.K., Hyde, K.D., 2014. The sooty moulds. Fungal Diversity 66(1), 1-36.

Domínguez-Serrano, D., Yanez-Morales, M.J., Garcia-Velasco, R., Alanis-Martinez, I., Segura-Leon, O., 2016. First report of Chrysanthemum morifolium leaf spot caused by Alternaria species in Mexico. Plant Disease 100(3), 647-647.

Elmer, W.H., Kamo, K.K., 2018. Diseases of Gladiolus. In: McGovern, R., Elmer, W. (Eds) , Handbook of Florists' Crops Diseases. Springer, Cham, 1289-1311.

Farhood, S., Hadian, S., 2012. First report of Alternaria leaf spot on Gerbera (Gerbera Jamesonii L.) in North of Iran. Advances in Environmental 6(2), 621-624.

Gault, S.M., Synge, P.M., 1971. Dictionary of roses in color. Madison Square Press, Grosset and Dunlap Publishers, New York.

Harisha, B.N., 2017. An Economic Analysis of Floriculture in India. Proceedings of the Sixth Middle East Conference on Global Business, Economics, Finance and Banking (ME17Dubai Conference) ISBN: 978-1-943579-18-1 Dubai - UAE. 6-8, October 2017. Paper ID: D748

Hotchkiss, E.S., 1983. Pathogenicity of Alternaria tagetica on Tagetes. Plant Disease 67, 1288-1290.

Kakade, D.S., Gurav, S.B., Singh, B.R., Nimbalker, C.A., 2006. Management of powdery mildew in rose under polyhouse condition. Journal of Ornamental Horticulture 9(4), 293-295.

Kang, S., Yan, M., Roundey, E., Lau, J., Pemberton, H.B., Bishop, C., Ong, K., Klein, P.E., Byrne, D., 2019. Resistance of garden roses to cercospora leaf spot. Acta Horticulturae 1232, 221-226.

Keller, J.R., 1950. New virus complex of chrysanthemums. New York. State Flower Grow. Bull 62, 2-5.

Kumar, G. A., Kamanna, B.C., Benagi, V.I., 2011. Management of chrysanthemum leaf blight caused by Alternaria alternata (fr.) Keissler under field condition. Plant Archives 11(1), 553-555.

Nishi, N., Muta, T., Ito, Y., Nakamura, M., Tsukiboshi, T., 2009. Ray speck of chrysanthemum caused by
Stemphylium lycopersici in Japan. Journal of General Plant Pathology 75(1), 80-82.

Noordam, D., 1952. Virus diseases of Chrysanthemum indicum in the Netherlands. Tijdschrift over Plantenziekten 58, 121-190.

Pérez Gutierrez, R.O.S.A., Hernandez Luna, H., Hernandez Garrido, S., 2006. Antioxidant activity of Tagetes erecta essential oil. Journal of the Chilean Chemical Society 51(2), 883-886.

Priyanka, D., Shalini, T., Navneet, V.K., 2013. A brief study on marigold (Tagetes species): a review. International Research Journal of Pharmacy 4(1), 43-48.

Qui, J. A., Castro-Concha, L. A., Garcia-Sosa, K., Pena-Rodriguez, L.M., Miranda-Ham, M.L., 2009. Differential effects of phytotoxic metabolites from Alternaria tagetica on Tagetes erecta cell cultures. Journal of General Plant Pathology 75(5), 331.

Riaz, T., Khan, S.N., Javaid, A., 2010. Management of Fusarium corm rot of gladiolus (Gladiolus grandiflorus sect. Blandus cv. Aarti) by using leaves of allelopathic plants. African Journal of Biotechnology 9(30), 4681-4686.

Saikia, S., Talukdar, M.C., 2017. Response of gerbera cV. Antibes to different organic growing media under naturally ventilated polyhouse. Journal of Ornamental Horticulture 20(3\&4), 147-152.

Sen, S., 1996. Occurrence of Alternaria leaf spot and flower blight on marigold (Tagetes erecta) in Himachal Pradesh. Indian Perfumer 40(4), 127.

Singh, R., Kumar, M., Raj, S., Kumar, S., 2014. Flowering and corm production in gladiolus (Gladiolus grandiflorus L.) Cv. "White Prosperity" as influenced by Integrated Nutrient management (INM). Annals of Horticulture 7(1), 36-42.

Singh, V.K., Singh, Y., Kumar, P., 2012. Diseases of Ornamental Plants and their Management. In: Singh, V.K., Singh, Y., Singh, A. (Eds.), Eco-friendly Innovative Approaches in Plant Disease Management. International Book Distributors and Publisher, New Delhi, 543-572.

Tomioka, K., Toyozo, S.A.T.O., Koganezawa, H., 2000. Marigold leaf spot caused by Alternaria tagetica new to Japan. Journal of General Plant Pathology 66(4), 294-298.

Torres, D.P., Silva, M.A., Furtado, G.Q., 2013. Infection of Curvularia gladioli on different gladiolus genotypes. Tropical Plant Pathology 38(6), 543-546.

Trolinger, J.C., McGovern, R.J., Elmer, W.H., Rechcigl, N.A., Shoemaker, C.M., 2017. Diseases of Chrysanthemum. Handbook of Florists' Crops Diseases, Springer, Cham, 1-66.

Trolinger, J.C., McGovern, R.J., Elmer, W.H., Rechcigl, N.A., Shoemaker, C.M., 2018. Diseases of Chrysanthemum. In: McGovern, R.J., Elmer, W.H. (Eds.), Handbook of Florists' Crops Diseases. Springer, Cham, 439-502.

Wick, R., Dicklow, B., 2013. Diseases of African Daisy (Gerbera jamesonii H. Bolus ex J.D., Hook). Scientia Agraria Curitiba 9(4), 481-489. 